きの $Q^{-1}$ の最高值は $1200^{\circ} \mathrm{C} て ゙ 1 \mathrm{~h}$ 加熱した $\mathrm{Fe}-20 \% \mathrm{Cr}$ 合金の $52 \times 10^{-3}$ である.

(3) 用性率 $G$ の $\gamma_{m}$ による变化率 $\Delta G / G_{0}=\left(G-G_{0}\right) / G_{0}$

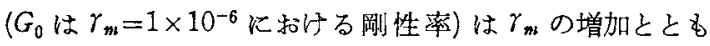
に徐々に減少してゆき，岁る $\gamma_{m}$ から急激に小さくなる。 その $\Delta G / G_{0}$ の変化の様子は $Q^{-1}$ の变化によく類似してい る. 一般に $\mathrm{Fe}$ 基吸振合金のQ $Q^{-1}$ は大きな磁湯のもとでは $1 \times 10^{-3}$ 程度の非常に小さな值になることから考元て，

$\mathrm{Fe}-\mathrm{Cr}$ 合金の $Q^{-1}$ がかな枕りさい值を示すのは磁気弾性 的履歷によるものと思われる。

(4) Fe-Cr 系合金の引張り強さ $\sigma_{t}$ および降状強さ $\sigma_{y}$ は $\mathrm{Cr}$ 量の增加ととむに大きくなっており，非金属あるいは 非鉄金属吸振材料に比べてかなり大きい。

\section{文献}

（1）堌本 量, 沢谷昭八, 比内正勝：日本金属学会誌, 41 (1977)，820; Trans.JIM, 18(1977), 581.

（2）増本 量, 沢谷昭八, 比内正勝：日本金属学会誌, 42(1978), 337 ; Trans.JIM, 19 (1978), 312.

(3) M.Koiwa and M.Hirabayashi : Sci.Rep.RITU, A-18(1966) , 344 .

(4) P.Kofstad, R.A.Butera and R.S.Craig : Rev. Sci.Instr., $33(1962), 850$.

(5) A.W.Cochardt : J.Appl. Mechanics, 20(1953), 196; Trans.ASM, 47 (1955), 440; Magnetic Properties of Metal and Alloys, ASM, (1958), 251.

(6) M.Hansen : Constitution of Binary Alloys, Second Edition, (1958) .

（7）今井勇之進，泉山昌夫，堌本 健：日本金属学会 誌, $30(1966), 284$.

(8) R.Becker and M. Kornetzki : Z. Phys., 88 $(1934), 634$.

\title{
プレストレストコンクリート鋼線材の瞬間加熱による ストレイン・テンパリングについて
}

\section{木 原 挐 二* 鳥 阪 泰 憲**}

Junji Kihara and Yasunori Torisaka : Strain-Tempering of Prestressed Concrete Steel Wire by Rapid Heating.

The strain-tempering by direct electrical resistance heating (heating time $=0.25 \mathrm{~s}$ ) was performed on the cold drawn wire of prestressed concrete steel.

Stress relaxation decreases without impairing of the mechanical properties such as total elongation, reduction of area, ultimate tensile strength and proof stress up to a straintempering temperature of $598 \mathrm{~K}$.

It is assumed that the improvement in relaxation behaviour by strain-tempering is not mainly due to the strain aging by free $\mathrm{C}$ and $\mathrm{N}$, but due to microscopic structure change generated by strain tempering stress with some thermal energy.

(Received November 10, 1978)

\section{I. 緒言}

先の報告(1)で，低炭素マルテンサイト鋼線材の極短時間 值接通電加熱(加熱脂間は 1.0 s) によるストレイン・テン バリング(以下 ST と略記する)について調べ，その結果， 極短時間直接通䉓加熱によるST は，ST 温度 $598 \mathrm{~K}$ まで は機城的性質に何ら変化を及注さず，酎レラクセーション 特性のみを著しく向上させ，特に ST 温度が $623 \mathrm{~K}$ では試 駼温度 $301 \mathrm{~K}$ に括けるレラクセーション值(以下 $\operatorname{Re}$ 值と 略記する)が $0 \%$ そなり，ST 温度 $548 \mathrm{~K}$ 以上では試験温 度が $433 \mathrm{~K}$ です 1.6\% 以下になることを示した。
一カ、プレストレストコンクリート(以下 PC と略記す る)鋼線材に打ける従来のST では, 酎レラクセーション 特性が向上しても，引張強さなどの機楉的性質が劣化する といわ䘛ており (Table 1) ${ }^{(2)}$, また現在, 約 $5 \mathrm{~s}$ 以内での加 熱時間による PC 鋼線のST 関する報告がないのて，低 䈐素マルテンサイト鋼線材 ${ }^{(1)}$ 同様に PC 鋼線材にも $0.25 \mathrm{~s}$ という極短時間直接通電加熱によるST を施し，耐レラク セーション特性拉よび他の機械的性質について調べると同 時に，STの耐レラクセーション特性向上に及洼す金属学 的原因に関し検討した。

* 東京大学工学部金属工学科 (Department of Metallurgy, Faculty of Engineering, University of Tokyo, Tokyo)

** 東京大学大学院, 現在：工業技術院機械技術研究所(Građuate School, University of Tokyo, Tokyo. Present address : Agency of Industrial Science and Technology, Mechanical Engineering Laboratory, Tokyo) 
Table 1 An example of a set of mechanical properties of PC wire after strain-tempering(2).

\begin{tabular}{l|r|r|r|r|r|r|r|r|r|r}
\hline \hline Treating temp. & \multicolumn{1}{|c|}{$473 \mathrm{~K}$} & $498 \mathrm{~K}$ & $523 \mathrm{~K}$ & $548 \mathrm{~K}$ & $573 \mathrm{~K}$ & $598 \mathrm{~K}$ & $623 \mathrm{~K}$ & $648 \mathrm{~K}$ & $673 \mathrm{~K}$ & $698 \mathrm{~K}$ \\
\hline$\sigma_{B}(\mathrm{MPa})$ & 1920.8 & 1920.8 & 1901.2 & 1901.2 & 1862.0 & 1852.2 & 1832.6 & 1842.4 & 1813.0 & 1783.6 \\
$\sigma_{0 .}^{2}(\mathrm{MPa})$ & 1901.2 & 1911.0 & 1871.8 & 1852.2 & 1813.0 & 1773.8 & 1715.0 & 1666.0 & 1597.4 & 1519.0 \\
$\sigma(\%)$ & 2.0 & 2.0 & 3.0 & 4.0 & 4.0 & 5.0 & 5.5 & 6.0 & 6.5 & 7.0 \\
\hline
\end{tabular}

\section{II. 実験試料，装置および方法}

実験に用いた試料は径 $6 \mathrm{~mm}$ ○ PC 鋼線材を冷間引技 きにより，径 $4 \mathrm{~mm}$ に落し(断面減少率は $55.6 \%$,引拔き 速度は $20 \mathrm{~mm} / \mathrm{s})$ ，Fig.1に示す寸法に加工したものであ Ђ.

Table 2 亿試料の化学組成を示す.

俣験装置は先に報告した低炭菜マルテンサイト鋼線材 (1) に用いたものと同様でありこの装置は Fig.2 に示すよ らに，スライドレギュレーター，タイマー,リングトラン スから成っている、リングトランスにより発生した電流 (低電圧・高電流)が Fig.1 亿示与試験片試料に供給され, この電流はスライドレギュレーターにより，制御されるの である。

垁験方法も低炭素マルテンサイト鋼線材 ${ }^{(1)}$ と同様であ

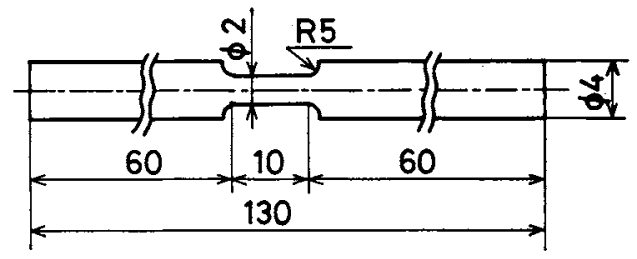

Fig.1 Size of specimen.

Table 2 Chemical composition of PC steel wire.

\begin{tabular}{c|c|c|c|c|c}
\hline \hline Compositions & $\mathrm{C}$ & $\mathrm{Mn}$ & $\mathrm{Si}$ & $\mathrm{P}$ & $\mathrm{S}$ \\
\hline wt\% & 0.747 & 0.760 & 0.270 & 0.014 & 0.017 \\
\hline
\end{tabular}

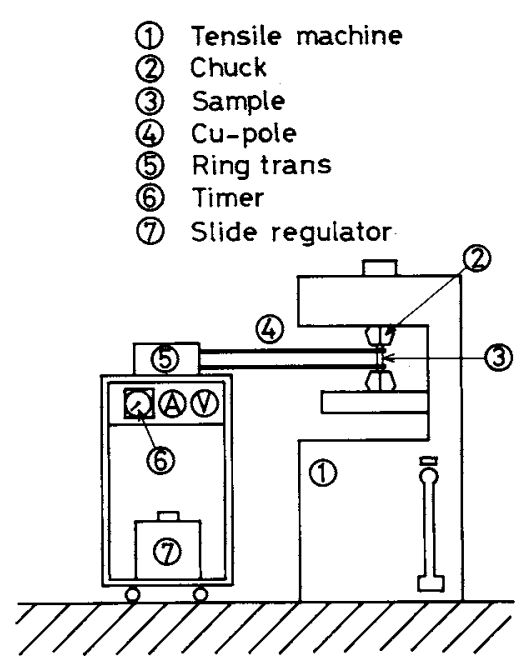

Fig.2 Apparatus for strain-tempering.
り，試験片にスポット溶接されたアルメルークロメル (C-A) 線をシンクロスコープに接続することにより，

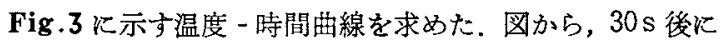
は完全に室温にもどっていることが分る、そこで，本実験 のST では通電後 $30 \mathrm{~s}$ 経過後, 除荷することにした。

$\mathrm{ST}$ 温度は $473 \mathrm{~K}$ から $623 \mathrm{~K}$ まで $25 \mathrm{~K}$ 間隔に 7 種類と し，それらの温度に対するスライドレギュレーター設定電 圧を知るため，Fig.3 と同様の曲線を 40,50,60,70V につ いても調べ，糈軸を最高到達温度(この温度を ST 温度と

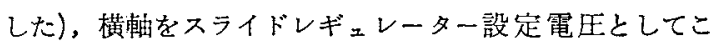
れらを一つにまとめてみた（Fig.4）。通電時間は 40〜80 V

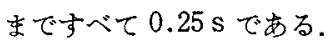

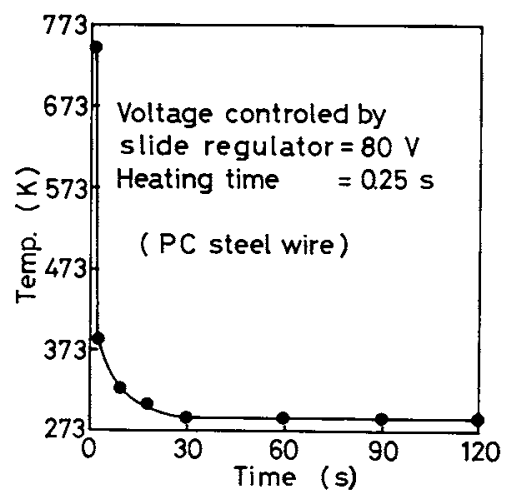

Fig.3 An example of time-temperature diagrams in strain-tempering.

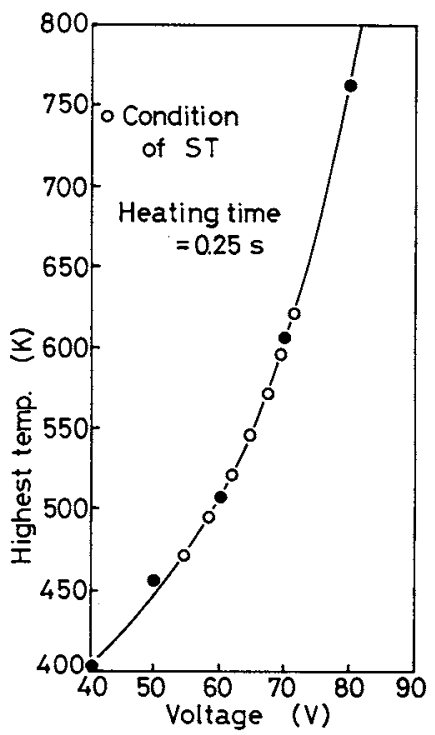

Fig.4 Relation between highest temperature and voltage controlled by a slide regulator. 
図中，一印は上記の最高到详温度，O印はST 温度のス ライドレギュレータ一設定電圧を知るために内そうした值 でそれらはそれぞれ 473〜 $623 \mathrm{~K}$ まで $25 \mathrm{~K}$ 間隔の最高 到達温度に対するスライドレギェレーター設定電生を示し ている。

ST 応力は引抜き材（引抜いたままの材料，すなわら ST を施していない材料のことで，以下 CD 材と略記する)の $0.2 \%$ 酎力の $80 \%(1164.2 \mathrm{MPa})$ とした。

Re 值の測定はすべて $10.8 \mathrm{ks} て ゙$ 行い，電気抵抗線ひず み計を利用した。Fig.5がその力法で，横軸は引張試験 機のロードセルからの荷重を，縦軸は䉓気抵抗線ひずみ 計からのひずみをそれぞれ示している。このとさの Re 值 はFig.5 に示すとおりである。

レラクセーション試験の初期応力は ST 応力と同様, 1164.2 MPa とした。

室温以上のレラクセーション試験では，加熱はリボンヒ

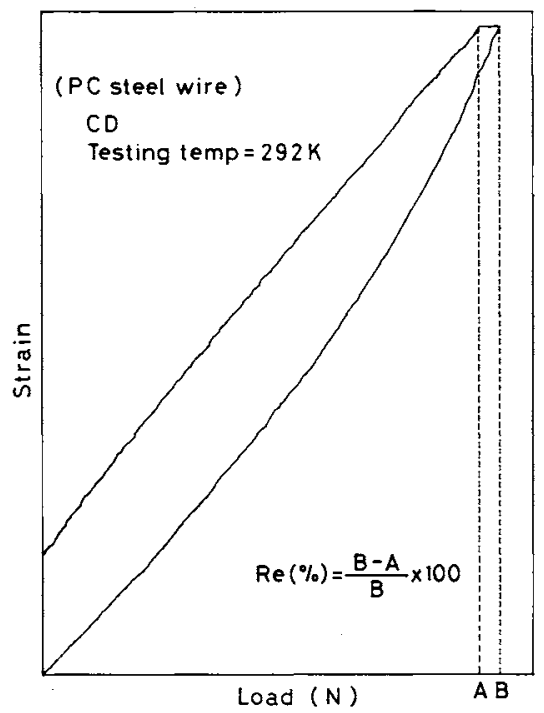

Fig.5 The sketches of load-strain diagrams during the relaxation test.
ータを用いて行い，試験片の平行部に貼布したひずみゲー ジに隣接した位置に C-A 熱電対を設定し，温度を計湘制 御した。

\section{III. 実 験 結 果}

Re 值に対するST 温度和よびレラクセーション試験温 度の影響をFig.6に示す。た Table 3 は図中の Re 値 および常温に括ける機械的性質をST温度に対して示した るのである。

Fig.6, Table 3 に拈いて, Re 値は和の执ののST 温 度に対する $292,363,433 \mathrm{~K}$ の 3 種類の試験温度での Re 值

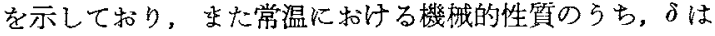
全伸びを， $\phi$ は絞りを， $\sigma_{B}$ は引張強さを， $\sigma_{0.2}$ は $0.2 \%$ 酎力を， $\sigma_{E}$ は弾性限をそれぞれ示している。

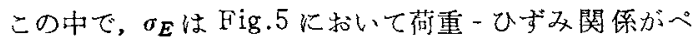
ンの幅だけ直線からずれる点として求めたものであり， $\sigma_{E}$ がB点を越える材料に対しては $\sigma_{E}>1164.2$ とした。

また， $\delta$ は試験片が規格外なので帮準試験片による値へ の換算を行った。すなわち，JIS-G3536では全伸びの沺定 は摽点間距離 $100 \mathrm{~mm}$ で行らように替定しているので,

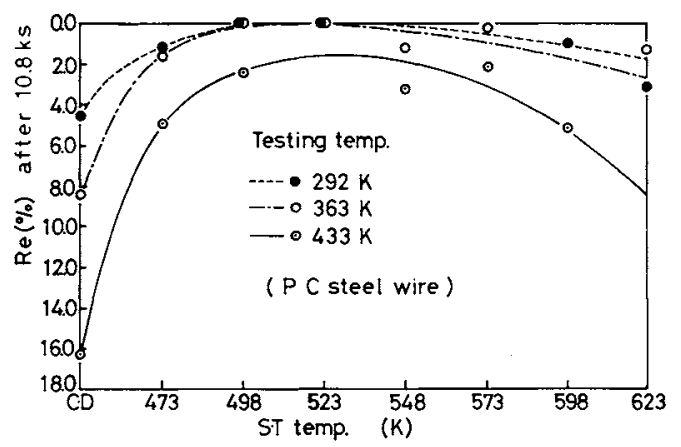

Fig.6 Relation between stress relaxation, $\mathrm{Re} \%$, and strain-tempering temperature.

Table 3 Mechanical properties and amount of relaxation, $\operatorname{Re} \%$.

\begin{tabular}{|c|c|c|c|c|c|c|c|c|}
\hline St.temp. (K) & $\mathrm{CD}$ & 473 & 498 & 523 & 548 & 573 & 598 & 623 \\
\hline $\begin{array}{l}\text { at } 292 \mathrm{~K} \\
\text { Re. } \\
\text { at } 363 \mathrm{~K} \\
\text { at } 433 \mathrm{~K}\end{array}$ & $\begin{array}{r}4.5 \\
8.4 \\
16.3\end{array}$ & $\begin{array}{l}1.2 \\
1.5 \\
4.9\end{array}$ & $\begin{array}{l}0.0 \\
0.0 \\
2.4\end{array}$ & $\begin{array}{r}0.0 \\
0.0 \\
-\end{array}$ & $\begin{array}{l}\overline{1.2} \\
3.2\end{array}$ & $\begin{array}{l}-\overline{0.24} \\
2.1\end{array}$ & $\begin{array}{c}0.97 \\
5 . \overline{17}\end{array}$ & $\begin{array}{l}3.18 \\
1.3 \\
-\end{array}$ \\
\hline$\delta(\%)$ & 2.7 & 2.9 & 2.8 & 3.2 & 2.9 & 2.5 & 3.5 & 2.3 \\
\hline$\phi(\%)$ & 54.4 & 43.8 & 47.4 & 39.9 & 39.9 & 43.8 & 36.0 & 39.9 \\
\hline$\sigma_{B}(\mathrm{MPa})$ & 1519 & 1568 & 1548 & 1582 & 1504 & 1560 & 1605 & 1249 \\
\hline$\sigma_{0.2}(\mathrm{MPa})$ & 1455 & 1493 & 1493 & 1516 & 1421 & 1504 & 1516 & 1203 \\
\hline \multicolumn{9}{|l|}{ (Continued) } \\
\hline $\begin{array}{ll} & \text { at } 292 \mathrm{~K} \\
\sigma_{E} & \text { at } 363 \mathrm{~K} \\
& \text { at } 433 \mathrm{~K}\end{array}$ & $\begin{array}{r}333 \\
237 \\
-\end{array}$ & $\begin{array}{l}570 \\
418 \\
481\end{array}$ & $\begin{array}{l}946 \\
921 \\
904\end{array}$ & $\begin{array}{r}1035 \\
933 \\
904\end{array}$ & $\begin{array}{r}1044 \\
800 \\
887\end{array}$ & $\begin{array}{r}1164 \\
921 \\
933\end{array}$ & $\begin{array}{l}927 \\
990 \\
921\end{array}$ & $\begin{array}{l}865 \\
851 \\
851\end{array}$ \\
\hline
\end{tabular}


その規定に合わせるため，次式で示す Barbaの相似法則 を用いた。

$$
\begin{aligned}
& \lambda=\alpha L_{0}+\beta A_{0}^{1 / 2} \\
& \text { ここで入：全伸び量 } \\
& \alpha, \beta \text { : 材料炕って決まった定数 } \\
& L_{0} \text { : 試験前の標点間距離 } \\
& A_{0} \text { : 圾験前の断面積 } \\
& \alpha L_{0} \text { : 一様伸び量 } \\
& \beta A_{0}^{1 / 2}: \text { 局部伸び量 }
\end{aligned}
$$

これらの図，表から，ST温度 $498 \mathrm{~K}$ から $573 \mathrm{~K}$ の間で $\operatorname{Re}$ の値が最む低下し，それ以上の温度では逆に增大して いることがわかる。 また，試験温度 $292 \mathrm{~K}$ と $363 \mathrm{~K}$ とで は，Re 值にそんなに大差はなく，殆えど同じである。

一方，機械的性質に関してはST 温度 $598 \mathrm{~K}$ ‡で $\delta, \phi$, $\sigma_{B}, \sigma_{0.2}$ ともにそえなと大差は認めら机ない。

$\mathrm{PC}$ 鋼線でも低炭素マルテンサイト鋼線材 (1) 同様に, ST 処理を施せば Table 3 に示すように，室温における $\sigma_{E}$ が著しく上昇するととるに、レラクセーション試験温度で の $\sigma_{E}$ も上异する(3)。 レラクセーション試験温度に和斿る $\sigma_{E}$ と $\operatorname{Re}$ 值との間には，西る種の刘応関係が存在してい

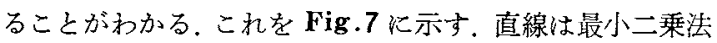
から求めたるので,レラクセーション試験温度 $363 \mathrm{~K}$ 以下 では直線何らの变化も見占れないが，試験温度が $433 \mathrm{~K}$ になると，值線が Re 値軸方向に移動することがわかる。

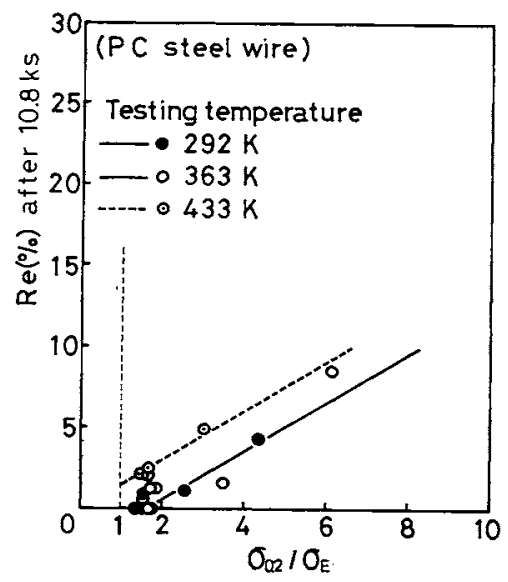

Fig.7 Relation between stress relaxation, Re\%, and the ratio proof stress, $\sigma_{0.2}$ to elastic limit, $\sigma_{E}$.

\section{IV. 考察}

$\mathrm{PC}$ 鋼線の ST 時間は $0.25 \mathrm{~s}$ と非常に短いため,この時 間内のST荷重を一定に保つこと㱠んぞ不可能である。

そこで，ST 時に推行る通電時の応力減少量を引張試験 機のロードセルから求めてみた，Fig.8がその結果であ る. 図中，横軸はST温度を，緃軸恃応力の減少量をそれ ぞれ示して括り，・印は弾性ひずみが塑性ひずみに变化し たために減少した応力を，○印は熱膨張により減少した応

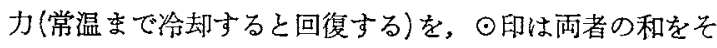

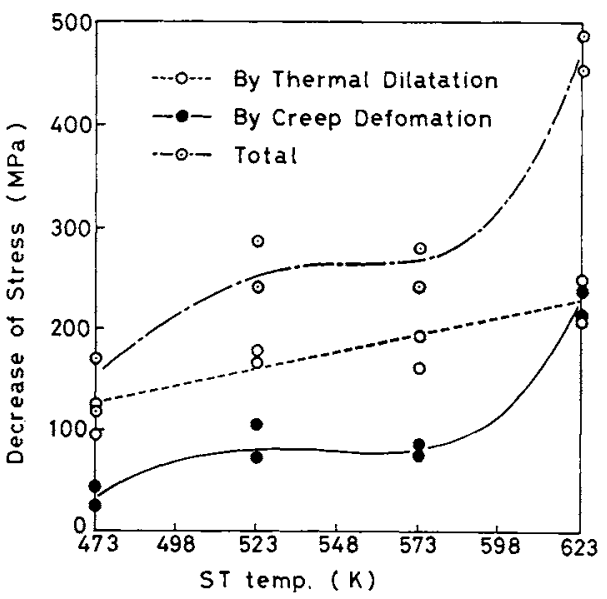

Fig.8 Variation of stress in strain-tempering at various temperatures.

れぞれ示したものである. 図より，ST 温度が $598 \mathrm{~K}$ 以上 になると，応力の減少が著しく，598 K では初期の ST 応 力の $26.4 \%, 623 \mathrm{~K}$ では $40.8 \%$ す減少している.

Fig.6で，ST 温度が $598 \mathrm{~K}$ を越えると，急に酎レラク セーション特性が劣化したのは上記の理由からであるうと 思われ，もし通電中にST 応力の低下がなければここよ らな劣化はなくなり，低炭素、ルテンサイト鋼線材 ${ }^{(1)}$ と同 様の曲線が得られたものと思われる。

ここで，鉄执よび岸素鋼の変形応力について考察してみ る.

一般に鉄の変形灾力は結晶粒の大きさ俄存する， $\sigma_{a}$ と， ひずみ速度拉よび盜度火依存する $\sigma_{t}$ に分けられる。

すなわち，

$$
\sigma=\sigma_{a}+\sigma_{t}
$$

$\sigma_{a}$ の粒度依存性は 1953 年, Petch ${ }^{(4)}$ が提唱したように， 平均粒度をdとすると $d^{-1 / 2}$ k比例するから次のように書 ける。

$$
\begin{aligned}
& \sigma_{a}=\sigma_{a}{ }^{0}+K_{a} \cdot d^{-1 / 2} \\
& \text { こご } d: \text { 結晶䊀の平均粒度 } \\
& \sigma_{a}{ }^{0}, K_{a}: \text { 定数 }
\end{aligned}
$$

一方， $\sigma_{t}$ 火ついては 1950 年代より多くの研究者によっ て取り扱われてきたが，鉄の変形速度が転位の動きやすさ によって決る点では異論はなく，その変形機構については 現在 2 つの考光方に別けられるよらである。

ひとつは Conrad らに代表されるるので(5)(6), 鉄の変形 が応力依存性をもり障害のポテンシャルU $\left(\sigma_{i}\right)$ と温度とに よって，そのひずみ速度が決ると考觉、これらの間にアレ ニウスの式

$$
\begin{aligned}
& \dot{\varepsilon}=\dot{\varepsilon}_{0} \exp \left(U\left(\sigma_{t}\right) / k T\right) \\
& \text { ここで } \dot{\varepsilon}: \text { ひする速度 } \\
& U\left(\sigma_{t}\right): \text { 変形に抗するポテンシャルェネルギー } \\
& k: \text { 执ルツマン定数 } \\
& T: \text { 絶対温度 } \\
& \dot{\varepsilon}_{0}: \text { 定数 }
\end{aligned}
$$




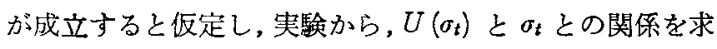
めて，これを熱力学的に考察することにより，鉄の变形は ダブルキンクの生成過程によって支配されているとしてい る.

他のひとつは Low Jr．らの考方方 ${ }^{(7)}$ で転位の運動は鉄 中の炭素と窒素原子の応力場によって抵抗をらけ，これが 鉄の変形を支配しているとするすのである。

五弓，木原 ${ }^{(8)}$ はひず久速度がアレ二ウスの式従らとい ら仮定のもとに，アレニウス式中の活性化エネルギーU と, 有効灾力 $\sigma_{t}$ (または $\Delta \sigma$ ) との関係を求めた，彼らはそ の関係が，普通炭素銅でかつ変形が主としてフニライト相 で起る場合には，室温付近でのひずみ速度と温度と変形応 力との関係を示するのであることに気ずき，木原は ${ }^{(9)}$ 次の ように数式化した。

$$
U\left(\sigma_{t}\right)=0.91-0.14 \ln \sigma_{t} \quad(\mathrm{eV})
$$

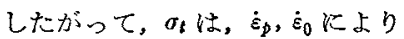

$$
\sigma_{t}=e^{6.5}\left(\dot{\varepsilon}_{p} / \dot{\varepsilon}_{0}\right)^{k T / 0.14}
$$

とあらわされる。ここで㐫は塑性ひずみ速度，他は通常 用いる変数である。なお， $\dot{\varepsilon}_{0}$ は一応可動転位密度の正の相 関の市るパラメータと考えてよい(5)(6)(8).

したがって，ブルーイング材とST 材の塑性ひずみ 0.2 \%以下において，完の大きさをしらべたり，両者の比較を行 うことは，ブルーイング材とST材の耐レラクセーション 特性の向上の同異を考察する上で興味のあることである。

そこで，ST材を $0.83 \mathrm{~mm} / \mathrm{s}$ ，ブルーイング材を 0.08 $\mathrm{mm} / \mathrm{s}$ で引張った結果を塑珄ひずみ $0.2 \%$ での範用に ついて，それぞれ Fig.9および Fig.10に示す。この実験 は本報告であつかった瞬間加熱処理による材料でのもので はなく，前報(10)で報告した実験に関連するものであって， 図中の $\sigma_{a}$ の値および材料の処理・化学成分柱全く前報之 同じである。

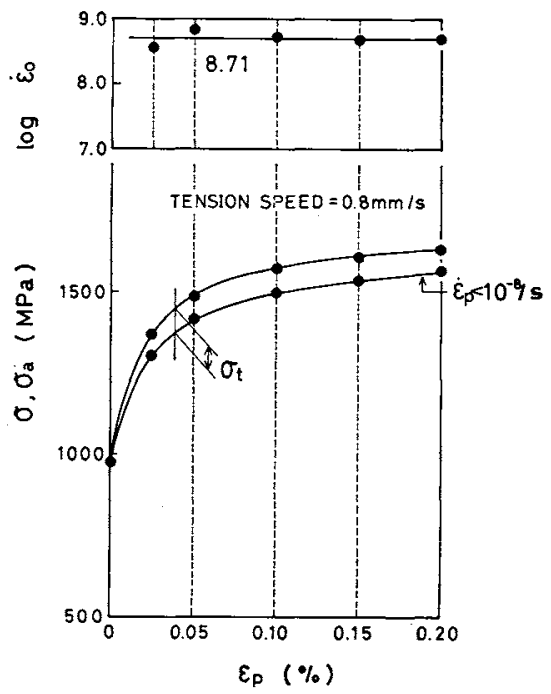

Fig.9 Creep curve and stress-plastic strain curve of strain-tempering wire. Nominal strain rate is $8.0 \times 10^{-3} / \mathrm{s}$.

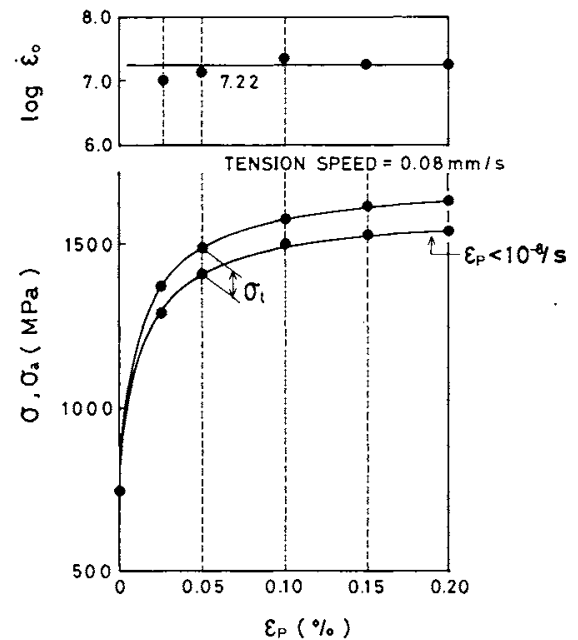

Fig.10 Creep curve and stress-plastic strain curve of blueing wire. Nominal strain rate is $8.0 \times 10^{-4} / \mathrm{s}$.

負荷中の荷重 - 伸び曲線に沿ってのひずみ速度の変動を 考慮にいれて算出した $\dot{\varepsilon}_{0}$ の值をそれぞれの图の上部に示 してある.ST材はブルーイング材より10倍大きい速度

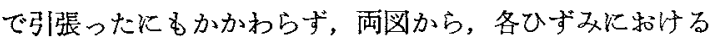
的に汪とんど差がなく，したがって式(5)からす明らかな よらに，両図に示す $\dot{\varepsilon}_{0}$ の值が ST 材の方がブルーイング 材より10倍大きいことがわかる。このことから可動転位 の釬付けはブルーイング材の方がより完全であることがわ かり，ST 材は $\dot{\varepsilon}_{0}$ が大きく，転位の釘付けは比較的甘い が，しかし代りに非熱的硬化を示すパラメータ $\sigma_{a}$ bを くなって, 耐レラクセーション特性に大きく寄与している ことがわかる。

本報で報告して来た瞬間加熱によるSTによっても十分 な耐レラクセーション特性の向上が得られるという事実 は，加熱時に負荷を行ならと転位の非保存運動により ST 材の構造が変化して，耐レラクセーション特性の向上をも たらすといら考えから，明確に理解できることと思われる。

\section{V. 結 言}

以上の実験結果から以下のことが分った。

(1) $\mathrm{ST}$ 温度 $598 \mathrm{~K}$ まで, $\delta, \phi, \sigma_{B}, \sigma_{0.2}$ 共に殆えど大差 は認められない。

(2) $\sigma_{E}$ と $\operatorname{Re}$ 值にはある種の対㐫関係が成立し，䉮便 渜レラクセーション試験の可能性が示された。

(3) ST 材はブルーイング材に比べて，変形㕯力のひず 速度依存性が小さい。

(4) STによる耐レラクセーション特性向上の主原因は

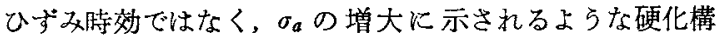
造の変化によるものと思われる。

最後に本研究を遂行するにあたり御指導下さいました 東京大学 宮川松男教授に深く感謝致します。 


\section{文献}

（1）鳥阪泰憲，木原諒二：日本金属学会誌，42(1978)， 51 .

（2）武富龟夫，勝又朝昭，坂村 杲，且井 准, 岩田 斉，里見样昭：住友電気技報，106(昭 47-5)，18.

(3) 鳥阪泰甞: 学位論文 $(1978-3)$, 東京大学.

(4) N.J.Petch : Progress in Met.Phys.s (1954), 1.

(5) H.Conrad: J.Iron Steel Inst., 198(1961), 364.

(6) H.Conrad and S. Frederick : Acta Met., 10 (1962), 1013.
(7) D.F.Stein, J.R.Low Jr.and A.U.Seybolt:Acta Met., 11 (1963), 1253.

（8）五弓勇雄，木原䛨二：日本金属学会誌，31 (1967), 368.

(9) 木原諪二：王延研究の進步々最新の生延技術， (1974-6)，p.31，日本鉄鋼協会(任延理論部会 20 問 年記念シンポジゥム)。

(10) 木原䛨二, 庵 文隆, 鳥阪泰害, 五弓勇雄：日本金 属学会誌, 42(1978), 114 .

\section{Y添加による $\mathrm{Fe}-20 \mathrm{Cr}$ 合金の高温耐酸化性改善効果*}

$$
\begin{array}{ll}
\text { 永井宏 } & \text { 村 并 照 幸*** } \\
\text { 岡 林 } & \text { 真***三 谷 裕 康** }
\end{array}
$$

Hiroshi Nagai, Teruyuki Murai, Makoto Okabayashi and Hiroyasu Mitani : The Improvement Effects of Yttrium Addition on the High-Temperature Oxidation Resistance of $\mathrm{Fe}-20 \mathrm{Cr}$ Alloy. The isothermal oxidation behavior of $\mathrm{Fe}-20 \mathrm{Cr}$ alloys with addition of $0.1,0.2,0.5,0.7,1.0$ and $1.4 \mathrm{wt} \% \mathrm{Y}$ was studied in air over the temperature range of $1273 \sim$ $1373 \mathrm{~K}$ by weight gain measurement, scanning electron microscopy, X-ray diffraction, electron probe microanalysis and ion microanalysis.

It was found that $0.1 \% \mathrm{Y}$ addition or more increased oxidation resistance at $1273 \mathrm{~K}$ and $0.7 \% \mathrm{Y}$ or more remarkably at 1323 and $1373 \mathrm{~K}$ compared to the base $\mathrm{Fe}-20 \mathrm{Cr}$ binary alloy. Generally an addition of $0.7 \% \mathrm{Y}$ gave the best improvement in the oxidation resistance. $\mathrm{Cr}_{2} \mathrm{O}_{3}$ was the major oxide formed on the alloys which exhibited a good oxidation resistance. Internal oxidation layer of $\mathrm{Y}_{2} \mathrm{O}_{3}$ was observed beneath the $\mathrm{Cr}_{2} \mathrm{O}_{3}$ scale of $\mathrm{Y}$ containing alloys. The growth of internal oxidation layer depth obeyed a parabolic rate law and the rate increased with increasing oxidation temperature and decreased with increasing $Y$ content in the alloys.

The ion microanalyser was used to analyse $\mathrm{Y}_{2} \mathrm{O}_{3}$ and $\mathrm{Fe}_{2} \mathrm{O}_{3}$ contents in $\mathrm{Cr}_{2} \mathrm{O}_{3}$ scales formed on $\mathrm{Fe}-20 \mathrm{Cr}-\mathrm{Y}$ alloys after $1 \mathrm{~h}$ oxidation. $\mathrm{Y}_{2} \mathrm{O}_{3}$ content increased, while $\mathrm{Fe}_{2} \mathrm{O}_{3}$ content remarkably decreased with increasing $\mathrm{Y}$ content in the alloy and slightly increased again over $0.7 \% \mathrm{Y}$. The $\mathrm{Fe}_{2} \mathrm{O}_{3}$ content in the scale formed after $1 \mathrm{~h}$ oxidation and the weight gain of $\mathrm{Fe}-20 \mathrm{Cr}-\mathrm{Y}$ alloys after $20 \mathrm{~h}$ oxidation showed the same dependency on $\mathrm{Y}$ content in the alloys.

The improvement effects of $\mathrm{Y}$ addition on the oxidation resistance of $\mathrm{Fe}-20 \mathrm{Cr}$ alloy were discussed from the view points of stabilization of $\mathrm{Cr}_{2} \mathrm{O}_{3}$ with dissolving $\mathrm{Y}_{2} \mathrm{O}_{3}$ and enrichment of internally oxidized particles beneath the scale.

(Received November 20, 1978)

\section{I. 緒 言}

著者らは前報 ${ }^{(1)}$ において，種々の希土類元素および活性 元素を添加した Fe-20Cr 合金の高温酸化挙動を検討し， 高温酎酸化性に及注す各添加元素の効果を比較検討した。 その結果,添加元素と酸素との親和力が大きい注どまた合 金中での移動度が大きい添加元素汪ど，酎酸化性改善効果 が大きくなることを予想した。すなわち，酸素との親和力 が強い添加元素は，(1) $\mathrm{Cr}_{2} \mathrm{O}_{3}$ 表面皮膜中激量固溶する
ことにより， $\mathrm{Cr}_{2} \mathrm{O}_{3}$ の分解酸素圧の低下すなわち $\mathrm{Cr}_{2} \mathrm{O}_{3}$ 皮 膜の安定化䊏与する(1)(2)のみならず，(2)ての低い酸素 压のもとて酸化皮膜直下に形成する内部酸化層にも影響 し、合金中での添加元素の移動度が大きい汪ど，また酸素压 が低い注ど，内部酸化層中の分散粒子密度が高くなり，金属 の拡散に対する物理的障壁としての効果が增大する。この 2 つの効果は, ともに $\mathrm{Cr}_{2} \mathrm{O}_{3}$ 皮膜への金属特に $\mathrm{Fe}$ の供給 を抑制して，耐酸化性を增大させるものと考光た。

**大阪大学工学部 (Faculty of Engineering, Osaka University, Osaka)

*** 大阪大学大学院 (Graduate School, Osaka University, Osaka)

* 1978 年 10 月 日本金属学会富山大会に発表 